\title{
A Holistic Defense for Shylock in The Merchant of Venice
}

\author{
Junjie $\mathrm{Yu}^{1}$ \\ ${ }^{1}$ Shandong University of Science and Technology, China \\ Correspondnce: Junjie Yu, College of Foreign Languages, Shandong University of Science and Technology, China. \\ E-mail: fish0165@126.com
}

Received: June 10, 2015 Accepted: July 3, 2015 Online Published: July 20, 2015

doi:10.5430/wjss.v2n2p38 URL: http://dx.doi.org/10.5430/wjss.v2n2p38

\begin{abstract}
The Merchant of Venice is a famous play of William Shakespeare, and the character Shylock is the most vivid and controversial character in this play. Traditionally, Shylock is criticized as a cruel, greedy and stubborn villain. However, in recent years, different viewpoints about Shylock begin to appear, which considered Shylock as a social victim and a loyal Jewish. In order to defend for Shylock, this thesis offers a detailed research on Shylock from the following three aspects: history background, the text and the author. All the three factors are important to get a proper understanding of a literary work. Therefore, the basic structure of this thesis is as follows.

The first part is an introduction. It mainly introduces the theme of the thesis, the author and the general plot of The Merchant of Venice and the theory evidence of the defense.

Chapter 1 is about the social and historical background of Shylock's time, and after presenting it, we may conclude that Shylock is a victim of social oppression and discrimination.

Chapter 2 is the analysis of Shylock in the text. By examining some dialogues and scenes, we may find several positive points hiding in Shylock's inside, which may arouse the reader's sympathy and understanding.

Chapter 3 explores the relationship between Shylock and Shakespeare. By comparison, we may see the similarities between the author and the character that he creates. In a certain sense, Shylock is Shakespeare.

Through the analysis from the above three aspects, Shylock is proved to be a social victim, a Jewish national hero and Shakespeare's alter ego.
\end{abstract}

Keywords: Shylock, Jew, defense, victim

\section{Introduction}

As we all know that The Merchant of Venice is one of the most successful works of the great British playwright William Shakespeare. And the Jew Shylock is certainly the most vivid character that towers over the whole play. In The Merchant of Venice, Shylock is an important character who is well known for money lending. The one thing that causes controversy in the play is the fact that he is Jewish which has left many people with different views on him.

The discussion of Shylock is always a hot topic in literature world. Often, Shylock, is viewed as a negative character, because in The Merchant of Venice he is portrayed as a beastly monstrosity with a lust for Antonio's life, whose action is considered as cruelty and stubbornness. However, in recent years, an opposite opinion generally appears, that is tragic character discussion, which views Shylock as a victim or a hero who suffers a lot from Christians. I am in favor of the latter opinion. In this thesis, I will present my viewpoint through analyzing the culture, religion and history background of that time, also the dialog and scene in the play which suggest this inner implication.

William Shakespeare, the world's best-known playwright, was born in Stratford-on-Avon in 1564, a hundred miles from London. In November 1582, when he was 18, he married the 26-year-old Anne Hathaway, who was pregnant with their first child, Susanna. Two years later they had twins, Hamnet and Judeth. It is believed that Shakespeare moved to London in 1586, finding work with a troupe of actors known as the "King's Men". At the time, it had become the fashion to build structures with no use other than playhouse. James Burbage built the first dedicated playhouse, dubbing it the "Theatre". It proved so popular that theatres began popping up around London in the ensuing years. By the time Shakespeare arrived, there was a large market for plays and playwrights in London. 
After learning the trade performing and altering anonymous plays, Shakespeare separated from the "King's Men", and began writing plays of his own, both freelancing and on commission for a company known as "Lord Chamberlain's Men". Shakespeare wrote The Merchant of Venice relatively early in his writing life. He wrote The Merchant of Venice somewhere between 1595-6. Although the exact date is unknown, scholars agree that it was written after Romeo and Juliet, and before Henry IV: Part II. The first recorded performance of the play was Sunday February 10th, 1605, at court for King James I. Obviously the performance went so well that the King ordered the other performance two days later.

The Merchant of Venice is significant as the first play Shakespeare wrote as a Dramatist first and poet second. The plays before it are famous for their long florid speeches, in which Shakespeare allows himself to wax poetical on every subject, using very beautiful words and phrases. While in The Merchant of Venice and the plays that followed, he had become a more restrained writer. Though he continued to indulge in his penchant for long speeches, now the speeches were mostly in service for the plot. The most notable aspect of the play is the character of Shylock, and his famous speech. It is interesting to note that at the time Shylock was regarded as more of a villain than he is today. When the play was first acted, there was little sympathy for him, and some surprised that he was let off so lightly. Modern analysts have questioned how Shakespeare actually felt towards Jews, to which the play offers no definitive answers.

The general plot of The Merchant of Venice is as follows. Bassanio is a failed merchant of Venice who falls in love with a rich woman named Portia who lives in Belmont. He needs some money so that he can travel to Belmont and convince her to marry him. And Portia also has a problem, because her father died without choosing a husband for her, a potential suitor would have to solve a puzzle involving chests. Bassanio's friend Antonio offers to borrow money to pay for the trip. Unfortunately, the loan shark, Shylock, has a grudge against Antonio because Antonio used to interfere with his business, and insult his religion at every opportunity. Therefore, Shylock plans to use this opportunity to take revenge on him. He loans Antonio the money on the condition that if he defaults on the loan, Shylock will get a pound of his flesh. Antonio agrees without considering the consequences seriously.

The heroine Portia is unhappy that she can't choose to marry the person she loves. What's worse, all her suitors either refuse to try to solve the puzzle, or are too stupid to figure it out. Portia gets word that a Venetian suitor will soon be arriving - she hopes that it is Bassanio, who she met a year earlier. In Venice, one of Shylock's servants leaves and becomes a servant for Bassanio - just as Shylock's daughter Jessica is planning to elope with Lorenzo, another of Bassanio's friends. While Shylock has dinner at Bassanio's house, Lorenzo and a few friends help Jessica escape from her house. Lorenzo and Jessica flee the city with some of Shylock's money. While Bassanio leaves for Belmont, Shylock scours the city with the help of the Duke of Venice, desperate to find his money, also his daughter.

Words get out that it is definitely Antonio's ship that crashed in the channel, leaving him without the money to pay back to Shylock. Shylock is angry about the loss of his daughter and money, while glad that he'll have the chance to take revenge on Antonio. In Belmont, Bassanio picks up the right chest and wins Portia for his wife. And Gratiano, Bassanio's friend, also marries Portia's maid Nerissa. Then a letter arrives from Antonio, saying that he's going to default on the debt, and Bassanio decides to go back to Venice to help him. Shylock has Antonio taken into custody in preparation for his trial. Portia and Nerissa, leave Belmont for Venice hoping to help their husbands, and she sends a letter to her cousin, a doctor in Padua.

The trial of Antonio starts in Venice. The Duke advises Shylock to be forgiving of Antonio, while Shylock refuses. Now being rich owing to his marriage, Bassanio offers Shylock three times of the money that Antonio owes but Shylock still refuses. The Duke had asked Doctor Bellario to come to Venice and decide the trial. Portia and Nerissa arrive, disguised in men's clothing, pretending to be a replacement doctor and his clerk. Portia pretends to stand by Shylock, and announces that he can cut a pound of flesh from Antonio. But she warns him about the finer points of the law that if Shylock takes anything more than an exact pound, it won't be a collection of a debt; it will be an attack on Antonio's life. As a Jew, Shylock is not a citizen of Venice, so if he attacks a citizen, he'll be sentenced to death, and all his property will be taken by the state. Shylock gives up and tries to leave, but Portia doesn't let him go on the grounds that he's given up on the debt, so his plan to attack Antonio has become a crime. And the punishment is that he has to give half of his money to Antonio, and the other half to the state. Finally, Antonio convinces the Duke to give Shylock half of his money back if Shylock agrees to convert to Christianity and give his money to his daughter and son-in-law. After the trail, a letter comes, saying that the rest of Antonio's ships have arrived safely at port, making him once again wealthy. At the end of the play all the characters are married, rich, Christian, and they all live happily ever after. That is the whole story of The Merchant of Venice.

To study a literary work, the following three factors are necessary to be considered: the work itself, the writing 
background and the author. That is to say, we should not only understand its plot, but also the social background of its birth, and the relationship between the author and character. Therefore, it is not wise to make comments on Shylock just through the surface script.

The theoretical evidence I will apply in this thesis is New Historicism, which inspires me to choose this subject. New Historicism is a theory applied to literature that suggests literature must be studied and interpreted within the context of both the history of the author and the history of the critic. New Historicists aim simultaneously to understand the work through its historical context and to understand cultural and intellectual history through literature, which documents the new discipline of the history of ideas.

The theory arose in the 1980s, and with Stephen Greenblatt as its main proponent, has become quite popular in the 1990s. Unlike previous historical criticism, which limits itself to simply demonstrating how a work is reflective of its time, New Historicism evaluates how the work is influenced by the time in which it was produced. It also examines the social sphere in which the author lives, the psychological background of the author, the books and theories that may have influenced the author, and any other factors which influence the work of art.

In addition, New Historicism indicates that any criticism of a work is necessarily tinged with the critic's beliefs, social structure, and so on. Most New Historicists may begin a critical reading of a novel by explaining themselves, their backgrounds, and their prejudices. Both the work and the reader are corrupted by everything that has influenced them. New Historicism thus represents a significant change from previous critical theories like New Criticism, because its main focus is to look at things outside of the work, instead of reading the text as a thing apart from the author.

In this thesis, I will apply the conception of New Historicism into the analysis of The Merchant of Venice and the character Shylock. Usually, readers just get to know the general plot of The Merchant of Venice, and Shylock is considered as a villain or monster in the play. In my opinion, that is rather superficial. Because Shylock has a special certificate that he is Jewish, it is not wise to judge him just through the story itself. Therefore, in order to get a proper understanding of the play and to make a justified comment on Shylock, we must take the history background and its author into account. In the following chapters, I will introduce a fresh Shylock image from these different aspects.

According to the above, the organization of my thesis is as follows.

Chapter 1 is about the social and historical background of Shylock's time, and after presenting it, we may conclude that Shylock is a victim of social oppression and discrimination.

Chapter 2 is the analysis of Shylock in the text. By examining some dialogs and scenes, we may find several positive points hiding in Shylock's inside, which may arouse the reader's sympathy and understanding.

Chapter 3 explores the relationship between Shylock and Shakespeare. By comparison, we may see the similarities between the author and the character that he creates. In a certain sense, Shylock is Shakespeare.

The last part is conclusion. Through the analysis of the above three aspects, Shylock is proved to be a social victim, a Jewish national hero and Shakespeare's alter ego.

\section{Shylock as a Social Victim}

As the New Historicism suggested, literature must be studied and interpreted within the context of both the writing background and the history of the author. Therefore, in order to get a proper understanding of Shakespeare's The Merchant of Venice, we need to know something about the history of Jews and the way Jews were regarded in the Renaissance and throughout English and European history. Fortunately, a good deal of materials has been unearthed on this subject, which may lead us to a conclusion that Shylock is in fact a social victim as a member of Jews.

\subsection{Jews in Early England}

Jews led an oppressed and miserable life in early England from their arrival in 1075 to the time when they were expelled in 1290. In 1075, a group of Jews came to England from Oxford and began to reside there, who are the first crowds of documented Jews in early England. English Jews were not confined to ghetto for more than a century, which is different from most of the European counterparts. Eyewitness describes that Jews and non-Jews visited each other's houses, and it indicated that they lived side by side in relative harmony. Jews, however, were not viewed as citizens. They were considered as outsiders, and were often forbidden from many professions due to their religion. The artisan guilds, the professional associations of the era, was only open to Christians. And the land also belonged to Christians. Therefore, Jews were left with few means of earning a living. However, Christians were forbidden to 
lend money with interest, therefore, many Jews earned a lucrative living as usurers. Yet this profession was not a save path to riches, because debts often had a way of going unpaid. The Jewish lender often had to collect his own debt, and try to regain the debt owed to him; he often became the target of resentment.

As usury was a profession comprised exclusively of Jews, religion eventually became the focus of much of this bad feeling. In the late $12^{\text {th }}$ century, the preparation for the Third Crusade heightened the sentiment of anti-Jewish. Anti-Semitic violence culminated in two massacres. One was at the coronation of Richard I in 1189, and 30 Jews were killed. The other was in 1190 in the city of York, when 150 Jews were massacred. The Magna Carta, the basis for English constitutional law, was itself a testament to the growing unpopularity of Jewish money-lending activities. Two clauses in the 1215 document state that if a debtor dies before his debt was paid; neither his heir nor his widow needed to repay the debt.

The measures and policies to compress Jews increased day after day, and Jews were living under the state of oppression. At last, in 1275, they were forbidden to be loan shark. And some other edicts against Jews were issued at that time, which included the taxation of any Jew over the age of 12 . What's more, Jews were required to wear badges to be identified as Jewish. As a result, their primary source of income had lost; therefore, they were of no value to the King's coffers. Consequently, Jews became expendable to the Crown and in 1290 they were expelled from England.

\subsection{Jews in Elizabethan Society}

From the mid- $16^{\text {th }}$ century, more and more Jews entered England and began to settle there, and were considered as "aliens" or "strangers". To a certain degree, the Elizabethan period was a time full of religious oppression. Shakespeare molded the figure of Shylock in a period when several images of Jews had been created by Christian writers, and these Jewish characters were widely viewed as figures of demonic evil.

In the mid- $16^{\text {th }}$ century, an increasing number of the alien presence began to appear in England. Later, from the late $16^{\text {th }}$ and early $16^{\text {th }}$ centuries, thousands upon thousands of immigrants entered England. Just like other successful centers of international trade at that time, London was crowded with outsiders: French, Dutch, Italians, Spaniards, Portuguese, and even a small number of Blacks and Jews were overcrowded within London's walls. The experts have estimated that these immigrants constituted nearly four or five percent of London's population in the late $16^{\text {th }}$ century, somewhere between five and ten thousand individuals. They were officially referred to as "aliens", or "strangers".

In terms of the extant materials, the English, especially Londoners, usually rejected foreigners. There arose fears of being overwhelmed. The threat that these strangers posed was imagined by some English subjects to be far greater than their actual power or numbers. In $16^{\text {th }}$ century, England was a heaven to the strangers, while in other times it was a hell. The infamous May Day riots of 1517, in which London's alien community was brutally attacked by apprentices, was just one case in point. The xenophobia was usually due to the economic jealousy. However, no matter what basis it had, the stereotype existed in Englishman's mind lasted for centuries in English history. The consistent xenophobic sentiment expedited the Crown's use of restrictive policy against the strangers as a bribe. On March 1, 1593, a bill to control the alien population was introduced into Parliament, and the excuse for this request is that the economic and political threat posed by the aliens is not only to the nation at large but also to native-born artisans.

Naturally, the minute part of Jews who managed to settle in England during this time belonged to that alien group. Londoners felt increasingly worried about their own financial status because of the financial success that the Jews won in their usury. Therefore, William Shakespeare's "alien" character Shylock in The Merchant of Venice shouldn't be interpreted regardless of the social background, which includes the tensions generated by Jews and their economic practices in London in the mid-1590s.

To a certain extent, the Elizabethan period was a time full of severe religious discrimination. The queen Elizabeth's father, Henry VIII, had broken with the Catholic Church to divorce his first wife and marry a second, Anne Boleyn, who gave birth to Elizabeth. Henry had broken and made many marriages in order to get a male heir. The loyal subjects of Elizabeth were expected to convert from Catholicism to the new Anglican Church just as her father's willing, although Elizabeth's elder sister, Mary had supported Catholicism. The Church of England, lucidly Protestant was the official established state religion in Shakespeare's time, and everyone was requested to attend an Anglican Service once a month. The Anglican service is also called Prayer Service, Prayer Book Service, Common Prayer; it was not legal for people to practice the faith according to their own choice. There were even fines to those who did not conform to the sanctioned religion; that is, for not going to Protestant services. 
In the climate of religious intolerance, Jews formed the most defensive alien group because of their religious otherness. After the Expulsion, the English view of Jews began to be influenced by some myths which grew in popularity through the centuries. The most impressive of the myths was ritual murder (or "blood libel"), which remained popular in England for a long time after the Jews had been expelled. There were some variations of this ritual murder legend, and the most popular one was that Jews kidnapped children at Easter and used them in ritual practices. It was also rumored that adult Christians would be killed and their blood be used for Passover ceremonies. None of these myths had any ground in reality; instead they were rooted in the fear of an unknown religion and, yet, they were viewed as truth by some people. As to the small quantity of Jews who managed to survive in England even after their expulsion in 1290, they were forced to convert to Christianity from Judaism and appeared outwardly to be Christians, though some still followed their Jewish heritage.

Englishman's enmity to the Jews appeared with the notorious event that impossibly had escaped from Shakespeare's notice. In 1593, several years before The Merchant of Venice was created, Queen Elizabeth I's physician Roderigo Lopez was accused of trying to poison her. Lopez, allegedly in league with the King of Spain, was convicted of treason, hung, and drawn and quartered in 1594. His trail was a very public execution, and the fact that he was a Marrano resulted in an outbreak of anti-Jewish sentiment in the country. He was taunted by slurs on the scaffold, and when he was dying, he was still proclaiming his innocence. It was obvious that there was a latent anti-Semitism within the English public. As a result, a lot of evil and murderous practices were attributed to Jews which often led to their wholesale massacre. As embodiments of the Devil, for instance, they were often charged with kidnapping and killing Christian children for their religion purposes. And, when the dread bubonic plague swept over Europe, they were accused of having begun the epidemics by poisoning the wells of their Christian neighbors. By that time, anti-Semitism in England had become prevalent.

Portraying Jewish characters in literary works had had a long history when Shakespeare began to write The Merchant of Venice. Usually, the church sponsored the touring troupes to perform the stories of the Old and New Testaments for a largely illiterate audience in the Middle Ages. These performances often aroused the medieval dichotomy of feeling about the Jewish race that had dogged Christianity. On the one hand, the audience admired Jewish patriarchs such as Moses, while on the other hand, they thought that Jews should be responsible for the crucifixion that the Christianity were suffering.

While the Renaissance was coming and anti-Semitism got its climax, that kind of biblical portrayal of Jews was replaced by an overly melodramatic perception. Jews became the evil embodiments in Elizabethan drama. Usually, Jewish characters were not complex for they were frequently portrayed as schemer or greedy figure or both. Jews are usually described as usurers and profiteers who are avaricious, mean, cunning and full of anxiety. Versions about Jewish villains could be found in Italy, France, Germany, as far as Serbia, and new misshapes were still being added in Shakespeare's own time. Those images were not consistent with the real Jews, but they reflected the Christian writers' bias towards Jews. It was the Jew's alienated place in the Christian hegemony that made those negative Jewish images exist. And the Jewish people are really bounded with evil. Shakespeare worked in creating the figure of Shylock in a period when this series of images were widely received that the Jew were viewed as hateful and greedy usurers, rather than any observable reality. In addition, he also derived material from received models that then appeared in the Elizabethan theater.

\subsection{Jews in Venice}

From the early $15^{\text {th }}$ century, Venice, the mercantile center in Europe, attracted many travelers, also Jews. The Jews began to settle down and made a living by lending money. They were seen as "aliens", not citizens, and they could only live in the Venetian ghetto because they refused to convert to Christianity.

Venice, a city in coastal northern Italy, was very famous in Shakespeare's time. It enjoyed the reputation of great wealth ("Venice the Rich"), political wisdom ("Venice the Wise"), impartial justice ("Venice the Just"), and liberalism, in sexual mores as in much else ("Venice the Gallant"). All of these attributes contributed to the "myth of Venice" as it was known and regarded in the $16^{\text {th }}$ century throughout Europe. Travelers, who came from England to the Continent going as far as Italy, invariably went to Venice and resided there for at least a few days. Several Englishmen, like Thomas Coryat and Fynes Moryson in the early $17^{\text {th }}$ century, have left long and detailed accounts of their visits. The myth of Venice was so powerful that it inspired not only William Shakespeare but also his great contemporary Ben Jonson as well.

Nevertheless, Venice attracted thousands of tourists for its status as the pleasure capital and its position in Europe as a rich mercantile center. They believed the myth, so they came and visited the city, and this became a major source of income of Venice. What' more, its commercial enterprise and reputation for liberty and justice also attracted a great 
number of Jews, who lived in the first ghetto in Europe that was founded in 1516. (Ghetto is the Italian for foundry; the place where the Jews were forced to live as a despised people was the site of an abandoned foundry.) From the mid- and late- $13^{\text {th }}$ century, Jewish loan bankers had begun to migrate to Venice. Some were from Germany where persecution was rampant, and others from central and southern Italy where had expelled the Jews.

Jews had been persecuted throughout Europe since the beginning of the Crusades. They were driven out of countries like England and France, and were in constant danger of losing lives and possessions. Some came to Venice, followed later by emigrants from Spain and Portugal expelled by the Inquisition, which relentlessly persecuted anyone who refused to convert to Christianity. The image of the Wandering Jew thus became a reality, as Jews looked for sanctuary wherever they could find it. Although there were severe restrictions in Venice, they could at least live in relative peace and security. But Jews were not well settled there until the late $16^{\text {th }}$ century. It owed largely to the exorbitant taxes imposed on them as a whole and also as a penalty for remaining infidels, that is, people who refused to convert to Christianity were aliens who could not be seen as citizens.

The only place in the city where Jews could reside is the Venetian ghetto that looked like a fortress. It had two major functions. One was to protect Jews from depredations of violence and plunder by riotous anti-Semites. And the other was to separate them from their Christian neighbors. The latter was because fraternizing may lead to intermarriage, which was forbidden, or conversion to Judaism, which was considered even worse. The ghetto had a single entrance which was guarded by police who also enforced the nightly curfew. If the ghetto was too crowded, it would become squalid and uncomfortable, all of which emphasized the inferiority of Jews to Christians. Jews were also enforced to wear different clothes, such as red or yellow badges and hats. They would be subjected to fines and imprisonment if they were caught outside the ghetto after curfew. In many ways, the ghetto anticipated modern concentration camps and racial discrimination. While owing to their highly useful economic function as bankers for the poor, taxpayers, creditors to the state and to individuals, the Jews in Venice were accepted as a segregated group and protected by the government. For these reasons, the repeated demands for their expulsion dwindled after 1573 and effectively disappeared by 1580 .

Whatsoever, Jews prospered in Venice. They were able to make their living, although they suffered from the discrimination against them and the limitations on their ability to earn a living, and were not permitted to own land or engage in many crafts as elsewhere in Europe. While unlike London, Venice allowed them to practice their religion openly. Generally speaking, Jews in Venice were treated better than they were in most other places. They lived there in peace and could be away from tyranny and violence. They could also get justice from "Venice the Just", where foreigners as well as citizens had equal rights before the law. And that is the basis for Shylock's appeal to the Duke.

The following is an excerpt that is extracted from Laurence Aldersey's account of his visit to Venice in 1581. It briefly describes the position of Jews in Venice and their customs, including the worship in their synagogues. This passage clearly illustrates the anti-Semitic attitudes being prevalent at that time. Aldersey also describes women, which suggests the great wealth Venetians enjoyed, even among working people.

The number of Jews is there thought to be 1,000, who dwell in a certain place of the city and have also a place to which they resort to pray, which is called the Jew's Synagogue. They all and their offspring use to wear red caps (for they are commanded) because there they may be known from other men. For my further knowledge of these people, I went into their synagogue upon a Saturday, which is their Sabbath day, and I found them in their service or prayers, very devout. They receive the five books of Moses and honor them by carrying them about their church, as papists do their cross.

Their synagogue is in form round and the people sit around it, and in the midst there is a place for him that reads to the rest. As for their apparel, all of them wear a large white lawn over their garments [i.e. the tallith, or prayer shawl], which reaches from their head down to the ground.

The Psalms they sing as we do, having no image nor using any manner of idolatry. Their error is that they believe not in Christ, nor yet receive that New Testament. This city of Venice is very fair and greatly to be commended, wherein is good order for all things, and also is very strong and populous. It stands upon the main sea and has many islands about it that belong to it.

To tell you the duke of Venice and of the Seignory: There is one chosen that ever bears the name of the duke, but in truth he is but servant to the Seignory, for of himself he can do little: it is no otherwise with him than with a priest that is at mess upon a festival day, which putting on his golden garment seems to be a great man, but if any man come unto him and crave some friendship at his hands, he will say, "You must go to the master of the parish, for I cannot pleasure you otherwise than by preferring of your suit." And so 
it is with the duke of Venice, if any man having a suit come to him and make his complaint and deliver his supplication, it is not for him help him, but he will tell him, "You must come this day or that day, and then I will prefer your suit to the Seignory and do you the best friendship that I may. " Furthermore, if any man bring a letter unto him, he may not open it but in the presence of the Seignory, and they are to see it first, which being read perhaps they will deliver it to him, perhaps not. Of the Seignory there be about three hundred and about forty of the Privy Council of Venice, who usually are arrayed in gowns of crimson satin or crimson damask when they sit in council.

As for the women in the Venice, they be rather monsters than women. Every shoemaker's or tailor's wife will have a gown of silk and one to carry up her train, wearing their shoes very near half a yard high from the ground. If a stranger meet one of them, he will surely think by the state that she goes with that he meets a lady.

\subsection{The Treatment of Jews}

Jews were dispersed all over the world after the fall of Jerusalem to the Romans in the first century of the Common Era and the destruction of the Second Temple. Most of them settled in Europe, North Africa, or elsewhere in the Middle East, while a small amount remained in what is now Israel. Although there were some minor outbreaks of violence, Jews generally got along with their neighbors during the first millennium. They clung fast to their own religion and refused to convert in that period. As Christianity rose and became dominant in Europe, followed by Islam in the Middle East and Africa, Jews continued to live more or less in peace despite the hostility of the church. That kind of situation lasted until the time of the First Crusade (1095-99). The fervor against infidels that the crusades inspired also provoked an often ferocious anti-Semitism, which led to the destruction of many Jewish communities. The rape, murder, and pillaging of bands of "poor men", led by fanatical priests, became sporadic and widespread across Europe. It culminated in the pogroms (massacres) of later centuries and ultimately to the decimation of European Jews in the Holocaust in World War II.

Until 1290, when Edward I expelled all Jews from England, communities of Jewish merchant, craftsmen, and other lived in different parts of the country. As elsewhere in Europe, they were considered as aliens and depended on rulers for protection and such rights as they had. They were treated as the sovereign's chattel or possessions and were heavily taxed. What's more, they were severely restricted in their way of life. They could not, for instance, own property. Hence, they resorted to what few livelihoods were permitted to them. A large mount of Jews engaged in money lending, although it is important to remember that not all Jews were poor and severed in a variety of capacities, including the most menial occupations. However, because they didn't believe in Christ, they were despised by Christians and treated accordingly. They were falsely by accused of poisoning wells and causing the plague, and even of ritual murder, despite Pope Innocent IV's bull of 1247, which exonerated them from such charges.

By the end of the thirteenth century, the king of England had exhausted almost all the resources he could get from his Jews in the form of heavy duties, or tallages. At last, he played his last card-expulsion. His action pleased the church and allowed him to confiscate all Jewish possessions, including all debts owed to them as moneylenders or pawnbrokers. There are some Jews who converted to Christianity and lived in the Domus conversorum (House of Converts), while most fled to other parts of Europe. Jews weren't officially permitted to return and practice their religion openly in England until the middle of the seventeenth century under the role of Oliver Cromwell.

Despite the expulsion edict of 1290, several communities of Jews secretly lived in England in the sixteenth century and probably earlier in cities like Bristol and London. Henry VIII had invited Jewish musicians to his court in the early 1500s; the Jewish engineer Joachim Gaunse, or Gans, came to England and helped found the mining industry in Wales. By Shakespeare's time a number of families lived in London and practiced their religion secretly, as recent scholarship has discovered. Many were Marranos, or crypto-Jews, who had come from Spain and Portugal, where under the Catholic Inquisition they were forced to convert to Christianity. Whether Shakespeare knew any Jews, or whether the Dark Lady of the sonnets was actually a member of the Bassano family who were Marranos, is not known for certain. What he did know or could hardly avoid knowing was the literary tradition in which Jews were represented.

During the Protestant Reformation, Martin Luther, in an early tract, "Christ Was Born a Jew" (1523) argued for better treatment of Jews, certainly if one hoped to convert them to Christianity. Luther appeals for Christian charity in dealing with the Jews:

If we really want to help them, we must be guided in our dealing with them not by papal law but by the 
law of Christian love. We must receive them cordially, and permit them to trade and work with us, that they may have occasion and opportunity to associate with us, hear our Christian teaching, and witness our Christian life. If some of them should prove stiff-necked, what of it? After all, we ourselves are not all good Christians either.

\subsection{Judaism and Christianity}

In The Merchant of Venice, the main conflict is between the Jewish Shylock and the Christian Antonio. And that conflict also reveals the contradiction between their religion beliefs which lead to their different thoughts and deeds. Therefore, it is necessary for us to be acquainted with the doctrines of the two kinds of religions-Judaism and Christianity.

The following is a chart which shows the comparison of Judaism and Christianity clearly.

Table 1. Comparison of Judaism and Christianity

\begin{tabular}{|l|l|}
\hline Judaism & Christianity \\
\hline God-centered, selfless & Man-centered, selfish \\
\hline Bible written by God, with Moses as secretary & New Testament written by man \\
\hline $\begin{array}{l}\text { Man's purpose is to serve God through His Law—-the } \\
\text { commandments. }\end{array}$ & $\begin{array}{l}\text { God's purpose is to serve man by providing } \\
\text { salvation—-for free. }\end{array}$ \\
\hline $\begin{array}{l}\text { Jews believe in Moses because God gave him } \\
\text { authority. }\end{array}$ & $\begin{array}{l}\text { Christians believe in Jesus because he gave himself } \\
\text { authority. }\end{array}$ \\
\hline $\begin{array}{l}\text { God controls evil, and uses it to punish sinners and for } \\
\text { other purposes. }\end{array}$ & $\begin{array}{l}\text { The devil controls evil, and uses it to rebel against } \\
\text { God. }\end{array}$ \\
\hline $\begin{array}{l}\text { Doing God's commandments is a privilege \& } \\
\text { opportunity that provides true freedom. }\end{array}$ & $\begin{array}{l}\text { God's law is a burden and a curse that enslaves and } \\
\text { condemns man. }\end{array}$ \\
\hline $\begin{array}{l}\text { God creates and runs the world to serve Him. } \\
\text { God creates man in His image; thus man has a soul } \\
\text { destroyed. }\end{array}$ & $\begin{array}{l}\text { Man creates God in his image; thus Jesus is declared } \\
\text { to be a deity. }\end{array}$ \\
\hline God's commandments are binding obligations. & $\begin{array}{l}\text { God's Law is a nice idea, but it is only "fruits of the } \\
\text { spirit," not a duty. }\end{array}$ \\
\hline
\end{tabular}

From the chart, we can see clearly that Judaism and Christianity are two completely different religions with their separated doctrines. They are both closer and farther apart than any two other religions. On the one hand, they are talking about the same thing with different viewpoints; but on the other, while dialogue between any two other religions may always fall back on the idea that they do not really contradict each other because they have no common ground, Jews and Christians both know who Jesus is, and fundamentally differ about who He is. He is the stumbling stone. Nevertheless, the conflict between the two religions is rather obvious, which is the root of the anti-Semitism.

Summary

It is just due to the special social background that we should analyze Shylock from a historicist perspective. Shylock, a member of Jews, is in fact a victim of anti-Semitism and social oppression. His religion belief is in great conflict with the dominate religion, which leads him to live in the lowest position of the society, and could only earn a living by money lending. Therefore, it is not proper to say that he is greedy. He is just struggling to survive. He is indeed a social victim.

\section{Shylock as a Rebel in the Text}

After getting acquainted with the writing and social background of The Merchant of Venice, let's analyze the controversial character Shylock in the text. Nevertheless, the text itself is the most important part to the readers. We 
can get some information from the plot and lines, which may show that Shylock is not a villain but a victim who need our sympathy. Mentioned The Merchant of Venice, it is first thought of Shylock, and the assessment of him seems to have been a foregone conclusion. As a typical usurer, Shylock always stands for greed, cunning, mean, cruelty. And together with Abagong, Chichikov Greek gold, Eugenie Grandet, he is called one of the world's four major stingy people.

Shylock, the so-called villain in the story, is a loan shark who despises Antonio. He plans to take advantage of Bassanio's situation by forcing him to default on the loan, allowing him to cut a pound of flesh from Antonio. He is bitter because of the horrible treatment he's received at Antonio's hands, and wants to take revenge. When Antonio defaults on the loan, Shylock takes him to court, but Portia, disguised as a doctor, uses Venice's laws against Shylock, leaving him robbed of his money and religion. That's the general plot of this play. It seems that Shylock is indeed a monster who desires a pound of fresh. However, after giving a detailed analysis of the story, we will make a different conclusion.

\subsection{Defense for Shylock's Cruelty}

Traditionally, most people regard Shylock as a cruel figure. Obviously, it is because that he refuses the double repayment from Bassanio and insists on a pound of Antonio's flesh. His action seems cruel. However, there is still a question: Why is Shylock so cruel like a monster?

Shylock may be cruel. But how do the Christians treat with him? Shylock is called infidel. His religious belief and his race are not respected. Everyone supports Antonio, even the duke who is the judge and should be fair. One of the reasons is that Shylock is a Jew, while Antonio is a Christian. After "That thou shalt see the difference of our spirits, I pardon thee thy life before thou ask it: For half thy wealth, it is Antonio's; the other half comes to the general state, which humbleness may drive unto a fine," says by the duke. Shylock says, "Nay, take my life and all; pardon not that: You take my house when you do take the prop that doth sustain my house; you take my life when you do take the means whereby I live."(Act IV, Scene I) This part is always considered as the evidence of Shylock's mean and greed. However, in my opinion, it expresses that the Christians discriminate against Jews and look down upon them. Shylock loves money very much, which seems the nature of Jews. However, Jews suffers a lot for a long history. They have no land, no country. The most reliable thing that they could depend on is money. Without money, they couldn't live their lives. Maybe that's the reason why Jews are the most successful businessmen in the world. Therefore, Shylock's so-called cruelty is in fact his revolt against oppression and discrimination.

Another important reason to say that it is unfair to describe Shylock as a cruel villain is his love to his daughter Jessica. Alexander Pushkin used to appraise Shylock as a man who dearly loves his families. In Act II, Scene V, one sentence hit the nail on the head, which is "Who bids thee call? I do not bid thee call." At that time, Shylock hurries to call Jessica to have supper, and Lorenzo help him to call Jessica's name. As a result, Shylock gets angry and abuses Lorenzo. Let's analyze the reasons. First, Lorenzo is an understrapper who has a low status. Therefore, Shylock feels uncomfortable to hear him call his daughter by name. It seems that Lorenzo's call would make Jessica's status be threatened. And second, Lorenzo is a Nazarene who has bad personal security, so Shylock feels ashamed to hear his daughter's name being called out of Lorenzo's mouth. Just from this scene, we can feel Shylock's protection to his daughter.

In the play, Shylock prescribes Jessica to fasten up the window and set aside the revel of the Nazarene. His purpose is to keep his daughter from the Nazarene's degeneracy, because in Shylock's mind, the Nazarene is vicious. While unfortunately, he pushes Jessica to the Nazarene due to his anxiety and drastic action. It also reveals Shylock's woeful side. On hearing that Jessica has sold his turquoise, he says in a voice cracking with emotion that "Out upon her! Thou torturest me, Tubal: it was my turquoise; I had it of Leah when I was a bachelor: I would not have given it for a wilderness of monkeys." (Act III, Scene I) Leah's identity is not introduced in the play, while she is generally regarded as Shylock's late wife, that is, Jessica's mother. We may feel his deep love for his late wife since he treasures the turquoise that she has given him. Therefore, there is no reason why he doesn't love their daughter.

Shylock has his good side of mercy, which he only uses to love Jessica. Only in Shylock's house, Jessica could be cared and reminded of shutting the doors and windows; and in the happy land of Bell Mountain, no one has ever formally accept her, no one talk to her (in addition to her husband and Lorenzo). She will always be outside the circle of alienation from the mainstream as a neglected person.Jessica holds a grudge against the betrayal and her last line is: "When I hear beautiful music, I can not easily." (Act V, Scene III) Beautiful music is a happy omen, can't makes her happy, because her father has been unfairly treated. Viewing from this, the majority of her uneasiness is not derived from the social and religious pressures, but because it is difficult for her to face the great father who bring 
her up. She has lived with Shylock for so many years, and no matter how meanly Shylock treats others, Jessica could know that her father is very concerned about her and never do any thing wrong to her.

Shylock's love for his daughter is not in a big way but remains hidden, and perhaps he himself is not clear how much he loves Jessica. Life, full of too much pain and hostility, forces him to put his arm up, never give a "love" word, never bare his emotional side. While Jessica will never put her father's guilt down, which is also a fact that indirectly reflects the kind-hearted and tragic side of Shylock.

Shylock is always under severe discrimination by the Christians, even by some modern readers, which can be shown by his name.

First, let's look up the dictionary and see how the word "Shylock" is explained. We can see that Shylock is referred to as a heartless or demanding creditor. What's more, a popular sentence that is often used by people is that "He is another Shylock". Obviously, Shylock has become a symbol of cruelty and stingy. In most cases, readers have already heard of Shylock's name before they read The Merchant of Venice. Therefore, Shylock has become a negative character in reader's mind, and it is difficult for them to reverse their stereotype.

Shylock appears in several scenes in The Merchant of Venice and has been mentioned by the other characters many times throughout the story, but seldom is he mentioned by his name "Shylock", instead, he is usually referred to as "the Jew", "dog Jew", and "currish Jew". Even various characters in the play hold serious doubts about whether or not to regard Shylock as a human being.

In the play, Shylock is often reduced to something other than human. In many cases, even the simple title of "Jew" is stripped away, and Shylock is not a man to the Christians, but an animal. For instance, Gratiano curses Shylock with "O, be thou damned, inexorable dog!", "currish spirit govern'd a wolf" and "desires are wolvish, bloody, starved, and ravenous" (Act IV, Scene I). Or when Shylock is neither a man or an animal, he becomes "a stony adversary, in human wretch"(Act IV, Scene II). When the Christians apply these labels to Shylock, they effectively strip him of his humanity, of his religious identity; he is reduced to something other than human.

When Shylock first appears in Act I, Scene III, Bassanio makes him acutely aware of his marginal status by approaching him solely to take out a loan of three thousand ducats. He appears himself a strangely isolated figure, secretive and calculating with his opening words: "three thousand ducats."

SHYLOCK: Three thousand ducats; well.

BASSANIO: Ay, sir, for three months.

SHYLOCK: For three months; well. (Act I, Scene III)

Here we see that Shylock has values that are generally despised in romantic comedies. Namely, he looks at everything in terms of money. There is something to the cadences of Shylock's speech in this scene that suggests that this is not a man one would make friends with. This is a man who is always calculating. Therefore, at the very beginning, Shylock is right away distanced from the audience.

The image of Shylock is the result closely related with the times. He is not a purely negative character or a cruel Jewish. Compared with the others, like Antonio, he is true and believable. Shylock picks up the sword of vengeance, by social, economic, ethnic and cultural factors. He is not only an avenger, but also a protestor and defenders.

\subsection{Defense for Shylock's Greed}

Usually, Shylock is considered as a greedy person, which is largely due to his career as a money-lender. However, in my opinion, we should comment on his career in a historical context. Through consulting the history of the Jewish, we may know that loan shark is the only way for them to survive in the world. In that time, Jews were forbidden to hold public posts or own the land. Money-lending seems to be the only way to make a living.

Shylock, living in Venice, has double identities. Not only is he a Jew, but also a money lender. These two identities decide that he must endure the unreasonable anti-Semitic acts of oppression and put up with the prejudice and curse that the whole Christian community do to usurers, which has made his situation even worse. As we all know, in the Middle Ages, the most despised job is usury. However, Jews, who live in medieval Europe in the Christian community, unfortunately, put a hook with this job. In most people's mind, the Jewish is synonymous with loan sharks.

Through history, we can see that the Jews are indeed the protagonist in lending industry in the Middle Ages, and Europe's financial activities are undertaken mostly by the Jews. However, Jewish are not born as financier, and the reason they has picked up the profession is mainly because of the existence of anti-Semitism. Due to the presence of 
anti-Semitism, Jews' choices on the career becomes less and less. It shows that the association between anti-Semitism and the phenomenon that medieval Jewish as moneylenders should not be that money-lending makes the Jews being hated, but being hated leads them to the moneylender path.

What's more, the seemingly lucrative money-lending business for the Jew is not completely free. As long as non-Jews believe that the enthusiasm of the Jews is a threat to them, they will give them the provisions of a number of prohibitions. The Jews are often subjected to exploitation and abuse. While without money, the Jews can not survive, so they have to make money for a seat of life and dwelling place.

At the beginning of the play, Shylock exhibits every sign of being the piece's villain. As the greedy Jewish usurer, he has become a stock character in Elizabethan drama. Shylock makes himself unhappy, with asides stating that he hates Antonio because Antonio is a Christian - but more he continues, because he lends money without interest, thus competing with Shylock's business and threatening Shylock's sole means of supporting himself and his family. When Antonio comes to ask him for money, Shylock immediately knows that his time for revenge has come. Shylock strikes a terrible bargain: the 3,000 ducats must be repaid in three months, or shylock will exact a pound of flesh from Antonio. His motive for revenge is so strong, even at a court of Justice in Venice, Shylock still insists on cutting "a pound of flesh" when the Duck asks Shylock to show mercy and declare that this is but a joke. As a shrewd money lender, Shylock is used to being calculating, but now he is possessed by anger that makes his speech rather spontaneous and emotional. Shylock uses rhetorical questions, parallel structure, antithesis and repetition to make this speech persuasively eloquent. For instance, Shylock:

\section{Why sweat they under burthens? Let their beds}

Be made as soft as yours and let their palates

Be season'd with such viands: You will answer

The slaves are ours. So do I answer you.

The pound of flesh, which I demand of him,

Is dearly bought; 'tis mine and I will have it.

If you deny me, fie upon your law,

There is no force in the decrees of Venice;

I stand for judgment: answer. Shall I have it? ( Act II, Scene III)

This piece goes beyond shylock's personal motivation for revenge. It represents an intense dissatisfaction with the anti-Semitism of the time.

In reality, Shylock is a wretched tragic personage in terms of the races of mankind and religion. His destiny likes a mirror which reflects the life of Jews in early England society. They were viewed as outsiders, and were often barred from many professions because of their religion. Only Christians could belong to the artisan guilds and own land, which left Jews with few means of earning a living. Christians, however, could not lend money with interest, and many Jews earned a lucrative living as usurers. This profession was not a sure path to riches, as debts often had a way of going unpaid. The Jewish lender often had to become his own debt collector, and in trying to regain the debt owed to him, he frequently became the target of resentment. As usury was a profession comprised exclusively of Jews, religion eventually became the focus of much of this bad feeling. In the late 12th century, preparation for the Third Crusade brought a heightened level of anti-Jewish sentiment. Shylock, as a Jewish character, is flawed and oppressed by the Christians surrounding him.

In The Merchant of Venice, the reader is told time and again of shylock's encounters with Christians and how they spits upon him, call him nasty epithets, and spurn him. Shylock is the very picture of a man who suffers much at the hands of his fellow men and who had finally reached his breaking point. Shylock hates Antonio as a Christian, hates him as an opponent of usury, and hates him for his spitting on Shylock's gabardine, calling him misbeliever and cut-throat dog. All the encounters give the Jew a stronger motive for revenge. In fact, we should use "revolt" instead of "revenge". Shylock, as a Jew, will fight for his suffering in Christian society. His revolt is decisive and unwavering, not only for himself, but for all Jews. It is obvious that to draw a pound of flesh will take Antonio's life, and Shylock has conspired to murder a Venetian citizen. Of course, there is no mention in the play that Shylock will use Antonio's blood in any religious ritual. But the audience will have immediately associated the stage action with the myth. In Portia, the audience gets the means to stop the ritual murder because she will not let the Jew shed one drop of Christian blood. Actually, it has already become a conflict in the religion of Jew and Christian. Shylock 
forfeits his wealth as well as his loan. Half is to go to the city, and half is to go to Antonio. Antonio later agrees to give back his half of the penalty on the condition that Shylock must bequeath it to his disinherited daughter, Jessica, and also convert to Christianity. Antonio shows mercy and tolerance to Shylock as a Christian, however, it is a mercy which forces someone to change his religion, and it is a tolerance which seizes someone all the wealth.

Viewing the play through modern eyes, Shylock can be seen as both an Elizabethan stereotype and a fully drawn human being. Ironically, it is precisely because of the stereotypical elements in Shylock's character that many people argue The Merchant of Venice is an anti-Semitic work. However, Shakespeare does not write a villain, but a complex character who defies explanation and who will revolt for his suffering even he is weak in society. Although Shylock is only a small literary figure in Shakespeare's plays, he has become a typical case as a Jew, as a victim of anti-Semitism, as the Jewish money lender, and as well as the experience of dispersed through the entire Jewish people for thousands of years. Shylock's seemingly greedy deed is in fact his revolt and revenge to the Christians.

\subsection{Defense for Shylock's Stubbornness}

To say Shylock is stubborn, it may be because of his attitude in the court. However, if we get acquainted with some doctrines and beliefs of the Judaism, we may make a different conclusion that Shylock is in fact a loyal Jewish, or a national hero, who fights for protecting his religion beliefs.

The Jews think that the advocacy of the spirit "fair" is extremely important to Judaism, or even the entire Jewish civilization is certainly built on the constant pursuit of "fairness". However, "forgiveness" is advocated by the Christian, and the core of Christianity is to teach people to love others, such as "Love your neighbor just like how you love yourself; love others just like how you want others to love you." Therefore, considering the doctrines of the Jewish, the reason why Shylock insists on the request of a pound of flesh is that he just requires the implementation of the "fair" verdict. That is certainly understanding and reasonable. The conflict between "fairness" and "forgiveness" in the play is the contradiction of the two kinds of religious morality on the surface, however, on a deep level, it is the opposing force between two kinds of different cultures. On the court in Venice, Shylock and Portia are two fighters separately on behalf of their own cultures, and they hold a deadly battle for their religion and culture.

To Shylock and the Jewish culture, giving Antonio Jesus-style "forgiveness" means to give up the Jewish culture and "fair" ideal, which means giving up their own cultural identity and their own identity. And all of them will become a shame that Shylock can not forget all his life. Although in The Merchant of Venice, Shylock is clearly vulnerable and will certainly miss the victory of lawsuit, he is a glorious through defeated fighter. He has made people a bit of shocked and admired from the heart. Shylock has the courage to face the test and frustration on the court with no servility, no fawning, because he believes that Portia is to win a case under the existing legal provisions, and all these are "fair". Shylock has always stuck to his understanding and beliefs of "fair", adhere to his religious cultural identity, and even in some aspects agree with everything of Jewish culture blindly. He firmly rejects to make any concessions and compromises on the cultural conflict. In a sense, despite of the strong tragic color, Shylock is still worthy of the representatives of the Jewish heroes.

Compared with the image of Shylock, those Christians, especially Antonio as a victim, presents his hypocrisy and scorn further more. After the failure of Shylock, the Duke of Venice is well-intentioned to require confiscating only half of Shylock's property for "forgiveness", while Antonio, with no slightest pity, is unwilling to let go easily and insists on confiscation of all of his property. What's more, he asks the court to force Shylock to convert to Christianity. Antonio can be seen as a Christian who is full of hypocrites; despite of the chants of "tolerance", his action shows not a little "tolerance" at all. By contrast, Shylock's the piety of Judaism is clearly highlighted.

In Venice, Shylock, as a Jewish usurer, has long been aware of his own religion location, and the risk of his social situation. But he insists on the recognition of the Jewish culture and never gives up the efforts to be understood by Christians. Shylock clearly demonstrates his Jewish cultural identity and high hopes for religious and cultural understanding when Bassanio comes to borrow money and invites him to dinner. He says: "I will buy with you, sell with you, talk with you, walk with you, and so following, but I will not eat with you, drink with you, nor pray with you." (Act I, Scene III) He makes it clear that, as long as local Christians respect his religious beliefs and customs, Shylock is willing to help them. When Antonio goes security for Bassanio, Shylock says more directly that his enmity with Antonio is mainly due to Antonio's groundless accusations to usury and in particular his exclusion of Jews and Jewish culture. Accompanied with the constant intensification of the contradictions with Antonio, Shylock's love for the Jewish culture and his pursuit of equality increasingly goes to sublimate. In the face of Antonio's relentless humiliation to the Jewish and the curse to usury, Shylock asks: "Do you vicious dog can also lend money to others? To a person who lend money to humiliate you?" (Act I, Scene II) The subsequent debate 
between the two men increases more rational color, and Shylock invokes an example in the Bible that Uncle Abram grazes sheep to get lamb to illustrate the "profit income" and "usury" to be reasonable legitimacy. He insists, "This was a way to thrive, and he was blest: And thrift is blessing, if men steal it not." (Act I, Scene III). Shylock's tirelessly efforts are not only to prove the legitimacy of usury which is attacked and abandoned by the Christians, but more importantly, they show Shylock's desire to be understood and recognized by the Christians, and the pursuit of equal social status.

As a shrewd businessman, Shylock is well aware that under normal circumstances, the possibility of effective implementation of the contract is almost zero, and he is clear about his sacrifices. But at the moment, he also weaving his dream, "I will be your friend, accept your love; I'll forget the past, you have the humiliation and hurt me, I will meet your needs, without any interest income." (Act I, Scene III). Despite the good intentions of Shylock, Antonio, is unmoved. Antonio has neither interest nor mood to contemplate the profound implication of this contract. He signs the contract arrogantly, and once again, ruthlessly rejects Shylock's desire for equality and the opportunities to be understood.

For centuries, Shylock has been condemned because of his "greed" and "cruel" manner on the court in Venice. In recent years, a scholar, David Bevington makes reposition and research of Shylock, saying that "the demand of Shylock for a pound of flesh as compensation, precisely represents his "flatly refused to the absurd truth of Christianity"". However, in my opinion, the image of Shylock in the play implies a more complex and profound significance. To Shylock, the requirement for Antonio to cut the pounds of meat or not, means choose the Christian's doctrine of "forgiveness", or Judaism's "fairness". What's more, it relates his choice of religious and cultural identity. In front of the conflict between two kinds of religions on the interpretation of "fairness" and "forgive", Shylock faces with a difficult choice. Finally, he chooses to call for "fair", and determines to fight for the completion of Jewish culture construction and Jewish identity confirmation in the Christian cultural hegemony.

However, Shylock has to yield under the hegemony of Christianity; his efforts on the reconciliation for Christianity and Judaism fail. Shylock sticks to his identity, and seeks for reconciliation. The action represents his concern for the entire Jewish people's future and their destiny. This is the thinking triggered by the conflicts between two kinds of culture in the drama, and it is also the refining and sublimation of the image of Shylock. As the pioneer anti-colonialist Frantz Fanon pointed out, "the Jews, because of their religious identity, history, race, and the relationship between ancestors and descendants, always under attack ... Thus, every time a Jew has been persecuted, in fact the entire Jewish people are subjected to humiliation together." Shylock is deeply aware of his own responsibility for the Jewish culture, and if he to give up pursuing "fair", it would mean a betrayal of their own peoples and cultures; he clearly understands the struggle against the Christian cultural hegemony, not only to their own cultural identity, but also for a good attribution of the Jewish compatriots and the Jewish culture. Therefore, for the Jews, Shylock is indeed a real Jewish national hero.

If we try to give a re-interpretation of this drama in a religious-cultural context, we would find that Shylock, as a infidel and cultural "otherness" in Venice, is always in the search for Jewish Culture self-construction and recognition of the Jewish identity and. Particularly, in the struggle against Christian cultural hegemony, Shylock insists on the Jewish faith and culture, and succeeds to the completion of the cultural identification and return of the national culture in his own unique way. In this Religious sense, Shylock is indeed a Jewish national and cultural hero.

\section{Summary}

After the analysis above, I believe that a fresh image of Shylock has appeared in our mind. Shylock is in fact a victim living under great oppression and discrimination, and what he has done is just his revolt and revenge to the Christians. He is an indeed good father who loves his daughter deeply. What's more, he is a royal Jewish who insists on his religion firmly. He is a rebel in the play, and the total repudiation to Shylock is obviously improper.

\section{Shylock as Shakespeare's Alter Ego}

Author is the soul of a literary work, because it is the author that gives birth to a work. The author determines the development of the plot, makes the description of his character and decides the ending of his story. The author's thought and voice appears in every corner of the story. Therefore, we must take the author into account if we want to analyze a literary work properly.

This chapter will explore the underlying relationship between the author William Shakespeare and his character Shylock. Shylock is a successful character that Shakespeare molded, who is also a controversial figure to the readers 
and critics. This character raises questions about Jews and anti-Semitism. He seems like a villain, but at the same time, he appeals our sympathy. Why did Shakespeare create such a figure like this? In my opinion, there is certain relationship between Shakespeare's inner thought and Shylock's actions, and he wants to say something through Shylock's mouth in order to express some of his own emotion. In a certain sense, Shylock is Shakespeare.

\subsection{Writing Background of The Merchant of Venice}

The first question that The Merchant of Venice raises is what kind of play it is. We need to know if it is a comedy, tragedy, tragic-comedy, or something else. Written in the mid-1590s, when Shakespeare's art was rapidly maturing, it shows the playwright experimenting with a variety of forms. He had just written the three plays of his "lyric period": a comedy, A Midsummer Night's Dream; a romantic comedy, Romeo and Juliet; and a history play chronicling the rise and fall of King Richard II. Some aspects of The Merchant of Venice derive from all three of these plays: its beautiful lyric poetry, found, for example, in Lorenzo's monologues in Act V; the comic antic of the clown, Lancelot Gobbo; and the downfall of Shylock. For modern audiences, however, the play raised certain issues that have led some critics to regard this play as a "problem play"; that is, a drama that raised significant moral questions that it fails satisfactorily to resolve, as in Shylock's forced conversion at the end of Act IV, Scene I.

Shakespeare wrote The Merchant of Venice at a time when few Jews lived in England, from where they had been forcibly expelled in 1290 by Edward I. Nevertheless, the Jew remained a powerful image in English literature and drama throughout the succeeding ages. The trial and execution of Queen Elizabeth's physician, Dr. Roderigo Lopez, in 1594; the revival of Marlowe's play, The Jew of Malta; and other events aroused renewed anti- Semitism in England and many have led Shakespeare to contemplate writing about a rich Jewish moneylender who, like Barabas in Marlow's play, acts a role of a villain. But unlike Marlowe, Shakespeare endowed his villain Shylock with some very human qualities that evoke much sympathy. The result is an ambivalence toward Shylock that makes his role one of the most dramatically complex and compelling among all of Shakespeare's characters, and one that reinforces the sense of this work as a problem play. Therefore, Shylock's value for literary research is still promising.

The Merchant of Venice is a puzzle. From its very first performance, audiences have been perplexed by it. They have wondered whose play it is. Is it Antonio's Portia's, or Shylock's? To answer this question, we must use the signposts that Shakespeare has given us as our guide. Let's begin with the title.

The title The Merchant of Venice is unique as a Shakespeare's title. It is one of few Shakespearean plays whose title is an occupation and a place. The title focuses on the homoerotic Christian Antonio, who coldly uses Shylock to defend his relationship with Bassanio against the intrusion of Portia, whose presence in Bassanio's life has plunged Antonio into a profound state of melancholic depression. Furthermore, The title also focuses on the humiliation and degradation of the socially necessary pariah Shylock, who represents the Mosaic origins which the Christian society tries either to hide but use, or to Christianize and absorb.

The title reveals that mercantilism is central to an understanding of intercultural and inter-social relationships. Although Antonio is the presumed merchant of the title, the title may suggest the merchanthood is paradigmatic for personhood, in which case everyone in the play is a merchant, and the absence of a name in the title points to all of us and not to any one in particular. This suggestion is strengthened if one considers that etymologically the words "merchant" and "merchandise" belong to the same family of Latin words that "mercenary" and "mercy" do, the family of Latin words that cluster around the word merces (fee, wages, reward). Perhaps, then the coin of the realm and the coin of the soul are more analogous than we like to think.

What's more, the title reveals that the play is set in Venice, the glittering and cosmopolitan port in which, if anywhere, disparate cultures should be able to meet and coexist peacefully and without contention. The merchant of Venice shows us a pariah, one whose pariah hood is most clearly illustrated in his refusal to eat with his Christian co-citizens, a refusal which is the external sign of his inability to pray with them. As Shylock himself says, in what must be considered an aside, even if it is not so marked in modern editions, when he is invited to dine with Bassanio and Antonio:

\section{BASSANIO: If it please you to dine with us.}

SHYLOCK: Yes, to smell pork; to eat of the habitation which your prophet the Nazarite conjured the devil into. I will buy with you, sell with you, talk with you, walk with you, and so following, but I will not eat with you, drink with you, nor pray with you. What news on the Rialto? Who is he comes here? (Act I, Scene III)

For pre-modern Christians, especially if one considers the iconographic significance of the Last Supper (even if they forget that it was a Passover dinner) and of the eating of the water at Mass, whoever would not eat with them could 
not be considered fully human. Shylock feels the pain of this dehumanization and the unrepentant attitude of the Christians, the result is that his daughter and his fortune have eloped with a Christian. Given the circumstances, if he did not feel conspired against and paranoid, we would be astonished. Shylock is no Tevye fiddling on the roof while his children and goods are absorbed into the Christian and secular society which surrounds them. The above is about what the title implies.

The presentation of Shylock, from his initial attempt apparently to befriend the Christians, despite their bestial persecution of him, to his final apparently craven acquiescence in his conversion to Christianity, constitutes an indictment of Jews whose practice so belies their principles that conversion seems only right and proper. Our reaction to Shylock's portrayal is a gauge of our understanding of the issues involved. Through the analysis of the above two chapters, we may have a feeling that Shylock's punishment is in fact undeserved.

\subsection{Shakespeare, Shylock and Anti-Semitism}

It is a well-known fact that anti-Semitism was highly prevalent throughout England during the Elizabethan era; however, it is unclear whether or not Shakespeare supports that same anti-Semitism through his presentation of Shylock, the main character of The Merchant of Venice. People have argued against and for the idea that Shakespeare presented Shylock in an anti-Semitic viewpoint, but no one will ever be able to prove who is actually correct on the issue. The only thing we can do is use evidence from the text and or from history itself to create a justifiable argument.

Of these arguments, there are two extremes, one ultimately claiming that Shakespeare is an anti-Semite, the other calling him a devout and praiseworthy humanist. In a textual analysis of Shylock's many speeches both of these conclusions can be made. It is how one interprets Shylock's words that will force one to see the validity in one conclusion over the other. H.B. Charleton, author of Shakespeare's Jew, vehemently suggests that the text compels us to believe that The Merchant of Venice endorses anti-Semitism. According to Charleton, Shylock's insatiable desire to take a pound of Antonio's Christian flesh represents the inhumanity of the Jew. He therefore concluded that Shakespeare's presentation of Shylock was an exploitation of the Jews, which in turn exposes Shakespeare as an anti-Semite.

Others have agreed with Charleton by saying that because Shakespeare creates Shylock as the stereotypical Jew of Elizabethan anti-Semitism, Shakespeare himself possesses these anti-Semitic beliefs. The Christians living in Venice viewed the Jews as murderous, greedy, and unmerciful. Shakespeare presents Shylock in such a way that he possesses all of these stereotypical characteristics. Shylock is a usurer meaning he lends money with escalating interest. In the eyes of the Venetians, lending money at interest makes him greedy. Also, Shylock's own words strengthen the customary image of the murderous Jew. After Shylock hears about Antonio's financial problems he proclaims, "I'm very glad of it. I'll plague him, I'll torture him, I am glad of it" (Act III, Scene I). A few lines later he reinforces the anti-Semitic stereotype of the Jew when he says, "I will have the heart of him if he forfeit, for were he out of Venice I can make what merchandise I will" (Act III, Scene I). Both murderous and greedy, Shylock is exactly a Venetian Christian's image of the Jew. For this very reason, many people have argued that Shakespeare was an anti-Semite.

An examination of the history of the Jews in England is important in giving validity to the claim that Shakespeare was an anti-Semite. The most important historical event to remember is the Jews being expelled from England. This happened three and a half centuries before Shakespeare wrote The Merchant of Venice. Therefore, Shakespeare's image of the Jew is most likely taken from passed down stories and literary sources which sketched the Jew as a greedy, hateful, and demonic person. Shakespeare probably had a distorted and unfavorable image of the Jews but that does not mean he is anti-Semitic, it only helps us understand why his character, Shylock, may have possessed some stereotypical characteristics.

Some people become sympathetic for Shylock. By analyzing the speech of Shylock, we can feel that Shakespeare is trying to express his own strong emotions through Shylock's mouth. Especially several monologues Shylock performs are so profound that they may reveal Shakespeare's inner thought. The instance many readers begin to feel for Shylock is when he exclaims the following typical lines of Shylock, which may show his inner side deeply if we taste them carefully.

SHYLOCK: To bait fish withal: if it will feed nothing else, it will feed my revenge.

He hath disgraced me, and hindered me half a million; laughed at my losses, mocked at my gains, scorned my nation, thwarted my bargains, cooled my friends, heated mine enemies; and what's his reason? 
I am a Jew. Hath not a Jew eyes? Hath not a Jew hands, organs, dimensions, senses, affections, passions? fed with the same food, hurt with the same weapons, subject to the same diseases, healed by the same means, warmed and cooled by the same winter and summer, as a Christian is?

If you prick us, do we not bleed? If you tickle us, do we not laugh? If you poison us, do we not die? And if you wrong us, shall we not revenge?

If we are like you in the rest, we will resemble you in that. If a Jew wrong a Christian, what is his humility? Revenge. If a Christian wrong a Jew, what should his sufferance be by Christian example?

Why, revenge. The villainy you teach me, I will execute, and it shall go hard but I will better the instruction. (Act III, Scene I).

After this speech, we feel for Shylock. He allows us to understand why he is so passionate about seeking revenge. All of the pain, embarrassment, and unfairness he has experienced throughout his life make his revenge justifiable. In this presentation of Shylock, Shakespeare allows people to believe that Shylock is just a man. He gets angry, he hurts, and he makes mistakes just like every other human being. He is not presenting Shylock as "the Jew" but rather as a man and therefore is in no way endorsing anti-Semitism. We don't believe that Shakespeare himself was anti-Semitic but we may believe that he used the historical backdrop of anti-Semitism in Venice during the Elizabethan era to create a play with historical validation that neither endorses nor subverts Elizabethan anti-Semitism. We like to think that Shakespeare, by virtue of his genius, was exempt from the prejudices of his time.

\subsection{Shylock as Shakespeare's Alter Ego}

In a certain sense, Shylock is Shakespeare, because they have several similarities, which can be shown by their names, their social status, their families and some of their feelings.

Let's start with their names. Shakespeare and Shylock's names have certain similarities, which is an interesting phenomenon. They both have a similar feeling on the tongue and in the ear. This point is exposed by Kenneth Gross in his famous book Shylock is Shakespeare. Gross links the historical and poetic in his own way when he provides an etymological account of the name "Shylock" and links it with the name "Shakespeare." There is the same breathy hush of the un-voiced sibilant "sh" that begins each one and the sharp shock of the unvoiced stop "k" at middle or end. The rhythm of the two hovers between a trochee and a spondee. Each binds two monosyllabic words, both of Anglo-Saxon derivation. The names show a similar two-step of adjective and noun or verb and noun, shy and shake, lock and spear, a feeling and an action, an opening and something that opens, also kills. What distance do we travel from one syllable to the next? Placed side by side, the names tempt various Joycings: Shakelock and Shyspear, Spysheer and Shapeshock, Lieshock and Slyshock, Sighlack and Shyblock; Speak-share, Spakehear, Shapekeeper, Shamedseeker, Shadeseer, Shockspeer and Shockcrier. "Shakespeare" sounds different when caught by the gravitational pull of "Shylock." The fictive name opens up the casket of the historical name, provokes it to dance or dream.

Then, let's look at their social status and careers. The character Shylock that Shakespeare has created is in fact himself. Shylock, like his author, is a creature of strange commerce, breeding money through what others think of as contaminated, unholy means, trading in a suspect currency that yet seems part of nature, not measurable goods, produce, land, labor, or services, but such odd stuff as words written on sheets of paper and spoken into the air, posturing bodies and souls, the flourishing of old hats, hose, feathers, cloaks, and swords.

Like Shylock's, Shakespeare's trade deals with the currency of desire itself pure and impure, something that is currency and commodity at once; Shakespeare, like Shylock, deals in strange promises, merry bonds with hidden stings. They both deal in the currency of debt, of wanting. It is not gold and silver but words that Shakespeare breeds as fast as Jacob's ewes. Shakespeare, like his moneylender, is a master of curious thrifts, a profiteer of loss, building his fortune on illegitimate gains, coining words real and counterfeit, circulating them within a suspect economy. Who knows more than Shakespeare about trading in and shaping the wants of men, those of his audiences and those of his actors, converting such wants to his own uses?

Shakespeare and Shylock are both professional gamblers, they play with loaded dice, they risk huge sums and insist on carrying out their contracts to the letter. They are both opportunists of reading and speaking, making capital of human weakness, error, and accident, trading in time and hazard. Within their inner ears even the words of abuse that others throw at them--the bestial Jew and the whorish player--can be turned to profit, made into the currency of inner lives. They can both make the dead tongue of the law speak for living, irrational hatreds. And they both create scenes, terrible scenes, dramatic moments that hold up to their audiences a mirror of their own needs, needs they cannot bear to know. 
Shakespeare's father is also a merchant; therefore, Shakespeare is a creature of commerce, breeding money through what others think of as contaminated, unholy means. What's more, Shakespeare is a commercial dramatist, so he has something in common with Shylock. When Shakespeare was a child, his father John was taken to court and had to pay a fine for money lending. He had leant 100 pounds at 20 percent interest - and made a whopping 20 pounds profit: Remember, you could buy a good house for 50 pounds in those days. The fine was only 40 shillings - that still left Mr. John S. with 18 pounds profit. That is usury to the uninformed.

Shylock is a money lender. The argument is frequently made that, because Shylock lends money, he is un-Christian and bad. The reality of the times was frequent use of money lenders: Is Shakespeare's play really condemning Shylock for money lending? In the London of his day, Shakespeare must have been in daily contact with merchants and money lenders, most would have been English and Christian, like his father. What were they saying? Because something is officially "illegal”, it doesn't mean people don't do it - one only had to leave the door of The Globe to bump into a prostitute. Shakespeare's father was also an elected member of his town council, someone handing out justice. And a further law case against John Shakespeare involves him buying and selling wool illegally. So he is a merchant, too.

What's more, Shakespeare and Shylock share some similarities in their feelings. The power of the character Shylock lies in what he reveals in more general terms about the human enigma, its jointure of freedom and dependence, alienness and complicity, for aggression and resentment, for giving itself over to the inhuman. The play explores what it means to inhabit this enigma, this divisive jointure, to expand it from within and force it into new combinations. Whatever is shown in Shylock strikes us more strongly given his stark isolation, and not just from his family or the society of Venice. Shylock is never visible, as Hamlet, Lear, Macbeth, and others are, to the world of the dead or the world of dream.

Shylock's isolation as character also reflects Shakespeare's isolation as author. As an author, Shakespeare always has troubles about the recognition from his audience and the understanding of his works. The significance of Shylock lies in what he reveals about the Shakespearean enigma as much as the human enigma. Shylock provides us a mirror of Shakespeare's sense of himself as a human author, as a creator of artifacts for the stage. We can see in Shylock's situation Shakespeare's comment on the risks entailed by his making, his joining together of exposure and deep self-concealment. Shylock shows us the vexed conditions of the playwright's success, in particular as he reflects something about Shakespeare's uncertain bond with his audience, the world that eats his children by eye and ear, a world on which Shakespeare takes his own kind of revenge.

Shylock's rage is also Shakespeare's rage, which includes, most centrally, the rage of Shakespeare the dramatic artist. In this he provides as powerful a clue to Shakespeare's artistic impulses as the characters of Hamlet, Falstaff, and Prospero. What The Merchant of Venice tells us about its author may be all the sharper given the play's awkward, imperfect shape as a theatrical artifact. As R. P. Blackmur noted in regard to certain texts of Henry James (for example, The Sacred Fount), "It is often in his relative failures that the artist's drive is most clearly defined; if only because in his purest successes there is the sense of the self-born, self-driven, and self-complete and these quantities escape definition."

Summary

As is discussed above, we may see that the author is indeed a key factor to the analysis of a literary work. Maybe his true intention is not exposed in his work obviously, but he does leave some hints if we taste it carefully. In my opinion, Shakespeare is not an anti-Semite; however, in his time he could not speak explicitly due to the historical conditions. Therefore, he chose to express his thought through the portrait of the character Shylock. He makes Shylock as his alter ego, and what he wants to say has been said through Shylock's mouth. The implied meaning is yet the true meaning of this play. Shylock has been testified not to be a blamed villain that most readers considered to be.

\section{Conclusion}

As is shown in the three chapters above, this thesis offers a detailed analysis of the character Shylock in Shakespeare's The Merchant of Venice. It aims to break up the traditional viewpoint and defend for Shylock, who is always blamed as a villain and a negative character in the play. What's more, it is also the rehabilitation of the Jews, who were discriminated and oppressed for a long history. The analysis is explored through the following three aspects: social background, the text itself and its author Shakespeare. Each aspect is necessary for a proper study of a literary work, and all the three aspects are analyzed in details in this thesis. 
Usually, Shylock is considered as a negative person in The Merchant of Venice, and he is always criticized as a cruel, greedy and stubborn Jewish. After the discussion, we may make a conclusion that Shylock is in fact a victim in his society. As a Jewish moneylender, he suffers from oppression and discrimination of Christians and what he has done is just his revolt and revenge. As to his living manner - money lending, it is the only way for him to survive in the world in his time due to the limitation of the Jewish career. He is a loving father and he loves his daughter very much. What's more, he is a royal Jewish who insists on his religion firmly. In a religious sense, Shylock is indeed a Jewish national and cultural hero. He needs our understanding and sympathy.

Shylock is a controversial figure that Shakespeare has created. He appeals our sympathy though he looks like a villain. Shakespeare expresses his thought through the portrait of the character Shylock. He makes Shylock as his alter ego, and what he wants to say has been said through Shylock's mouth. In a certain sense, Shylock is Shakespeare.

The theory significance of the thesis is to enrich the research about the character Shylock in The Merchant of Venice, since he is still a controversial character till now in the literary world. The practical application value of the research is that it conforms to the time subject anti-Semitism. Anti-Semitism is still a hot topic in modern society, because it is closely related to the peace of the modern world. Through the research of the Jewish character Shylock and the social background of his time, we may get some deep understanding to the Jews and anti-Semitism. Therefore the discussion of this topic also has certain practical and social meaning.

William Shakespeare is such a great writer in literature world that research about him and his works will never stop. Hence there is still much space to be explored on the study of Shakespeare and The Merchant of Venice, and Shylock is still a controversial character to be argued further more. I will continue to do deeper research on this subject in the future.

\section{References}

Aldersey, Laurence. (1978). Account of Venice 1581. Glasgow: James Maclehose and Sons.

Andrew, John. (1985). William Shakespeare: His world, His work, His influence. New York: New York Scribner.

Calisch, E. N. (1999). The Jew in English Literature. Washington: Kennikat Press.

Cheyette, Bryan. (1999). The Image of the Jew in European Liberal Culture 1989-1914. London: Vallentine Mitchell Press.

Fisch, Harold. (1991). The Dual Image: The Figure of the Jew in English and American Literature. New York: Ktav Publishing House.

Gildon, Charles. (1967). Remarks on the Plays of Shakespeare. The Works of Mr. William Shakespeare, Vol, 7. New York: AMS Press.

Glock, Charles Y. (1966). Christian Beliefs and Anti-Semitism. New York: Harper and Row.

Gross, Kenneth. (2006). Shylock is Shakespeare. Chicago: University of Chicago Press.

Halio, Jay. L. (1998). Understanding The Merchant of Venice. Beijing: Renmin University of China Press.

J. R. Brown. (1987). Shakespeare and His Comedies. London: Vallentine Mitchell Press.

Kramer, Michael. (2000). Jewish American Literature. New York: Columbia University Press.

Lelyveld, Toby. (1990) Shylock on the Stage. Cleveland: Press of Western Reserve University.

Lippman, Laura. (1997). William Shakespeare's The Merchant of Venice. Chicago: University of Chicago Press.

Mcpherson, David. (1990). Shakespeare, Jonson, and the Myth of Venice. Newark: University of Delaware Press.

Rabkin, Norman. (1981). "Meaning and The Merchant of Venice". Shakespeare and the Problem of Meaning. Chicago: University of Chicago Press.

Roth, Cecil. (1964). A History of the Jews in England. Oxford: Oxford University Press.

Shakespeare, William. (1994). The Merchant of Venice. Beijing: Penguin Books.

Shapiro, James. (1997). Shakespeare and the Jews. New York: Columbia University Press.

Sinsheimer, Hermann. (1968). Shylock: The History of a Character. New York: Benjamin Blom.

Yaffe, Martin D. (1997). Shylock and the Jewish Question. Baltimore: Johns Hopkins University Press. 